\author{
Adam Przepiórkowski @i https://orcid.org/0000-0002-4398-2636 \\ University of Warsaw \\ Institute of Computer Science, Polish Academy of Sciences \\ University of Oxford
}

\author{
Agnieszka Patejuk ๑ https://orcid.org/0000-0002-2367-9170 \\ Institute of Computer Science, Polish Academy of Sciences \\ University of Oxford
}

\title{
Predicative Adverbs and Adjectives with Infinitival Subjects. A Corpus Investigation
}

\begin{abstract}
The aim of this paper is to compare two Polish predicative constructions with infinitival subjects, namely those with predicative adverbs and those with predicative adjectives. The latter construction, of the form "predicative adjective + copula + infinitival subject", has hardly been noticed in Polish literature on predication, copulas, or infinitival subjects. On the basis of corpus data, mainly from the National Corpus of Polish, we demonstrate that this construction is much rarer than the analogous construction with predicative adverbs. We also show that roughly the same predicates may be expressed as either adverbs or as adjectives when the subject is an infinitival phrase - any observed differences are not systematic but rather stem from lexical gaps and differences in the meanings of particular adverbs and adjectives. In particular, certain modal predicates may only be expressed as adjectives because the corresponding adverbs do not express the same non-epistemic modal meanings. Finally, we provide new corpus evidence for an earlier claim that predicative adjectives are much rarer than adverbs when the subject is infinitival because they require this subject to undergo covert nominalisation; as adverbs combine with infinitival subjects directly, they are usually preferred.
\end{abstract}

\section{Keywords}

predicative adverbs, predicative adjectives, infinitival subjects, non-epistemic modality, Polish, corpora. 


\section{Streszczenie}

Celem artykułu jest porównanie ze sobą dwóch konstrukcji predykatywnych w języku polskim, w których podmiotem jest fraza bezokolicznikowa: konstrukcji z przysłówkami predykatywnymi i konstrukcji z przymiotnikami predykatywnymi. Ta ostatnia konstrukcja, o postaci „przymiotnik predykatywny + łącznik + podmiot bezokolicznikowy”, nie została wcześniej opisana w polskiej literaturze dotyczącej predykacji, łączników czy podmiotów bezokolicznikowych. Na podstawie danych korpusowych, przede wszystkim z Narodowego Korpusu Języka Polskiego, pokazujemy, że konstrukcja ta jest znacznie rzadsza niż analogiczna konstrukcja z przysłówkami predykatywnymi. Twierdzimy także, że w zasadzie te same predykaty mogą zostać zrealizowane albo jako przysłówki, albo jako przymiotniki, gdy podmiotem jest fraza bezokolicznikowa - obserwowane różnice nie mają charakteru systemowego, a wynikają jedynie z braków w leksykonie lub z tego, że nie zawsze przymiotniki i odpowiadające im przysłówki mają te same zestawy znaczeń. W szczególności pewne predykaty wyrażające modalność nieepistemiczną mogą być wyrażone tylko za pomocą przymiotników, gdyż odpowiadające im przysłówki nie wyrażają takiej modalności. Artykuł omawia także nowe dane korpusowe stanowiące dodatkowy argument za hipotezą, że przyczyną znacznie niższej frekwencji przymiotników predykatywnych niż przysłówków w omawianych konstrukcjach jest to, że - aby możliwe było połączenie przymiotnika predykatywnego z podmiotem bezokolicznikowym - podmiot ten musi ulec składniowej nominalizacji, podczas gdy przysłówki mogą łączyć się z podmiotami bezokolicznikowymi bezpośrednio; stąd preferencja dla składniowo prostszych konstrukcji z przysłówkami.

\section{Słowa kluczowe}

przysłówki predykatywne, przymiotniki predykatywne, podmioty bezokolicznikowe, modalność nieepistemiczna, język polski, korpusy.

\section{Introduction}

The aim of this paper is to examine Polish predicative constructions involving an infinitival subject of predication (i.e. a predicand) and an adverbial or adjectival predicate, as in (1) and (2), respectively (both from the National Corpus of Polish; NKJP). ${ }^{1}$

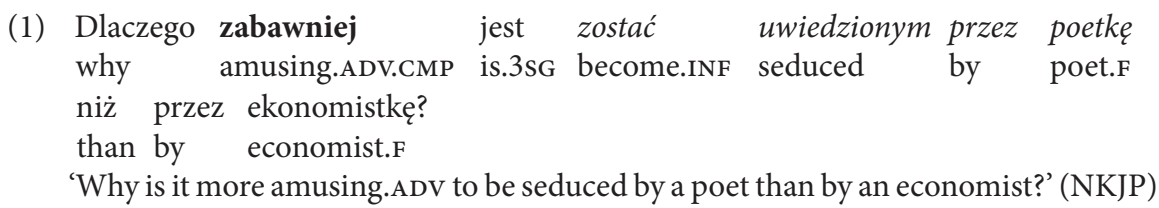

1 Throughout the paper, meanings of Polish predicative adverbs are given with reference to English adjectives, e.g., TRUDNO 'difficult', rather than 'difficultly'. (Sometimes, for greater perspicuity, ADV or ADJ are added to indicate the part of speech of the Polish word, as in 'amusing.ADV' in (1) and 'amusing.ADJ' in (2).) In numbered examples, predicative adverbs and adjectives are in bold, and infinitival predicands are in italics. Morphosyntactic abbreviations follow the Leipzig Glossing Rules (https://www.eva.mpg.de/lingua/resources/glossing-rules.php); additionally, CMP stands for "comparative" and sup for "superlative." 
(2) Wanda żartowała, że całkiem zabawne jest wracać Wanda joked COMP quite amusing.ADJ.NOM.SG.N is.3sG return.INF $z \quad$ knajpy $z \quad$ własnym mężem.

from pub with own husband

'Wanda joked that it is quite amusing.ADJ to come back from the pub with one's own husband.' (NKJP)

Constructions with predicative adverbs and infinitival predicands, as in (1), were noted in Grzegorczykowa 1975: 35-36, and they have received some attention in subsequent literature (e.g., Szupryczyńska 1995a, 1995b and, more recently, Patejuk and Przepiórkowski 2018, 2020). ${ }^{2}$ They have also been covered in various descriptions of the combinatory potential of the copula BYć 'be' (e.g., Saloni and Świdziński 1985, 2007: 164; Saloni 1990, 2000; Żmigrodzki 1991; Kallas 1993; Bondaruk 2013: ch.IV).

By contrast, constructions with predicative adjectives and infinitival predicands, as in (2), have not been taken into account in previous work on BYć 'be'; to the best of our knowledge, they were first analysed in Patejuk and Przepiórkowski 2018, 2020. ${ }^{3}$ It is argued there that in both constructions - those involving predicative adverbs (as in (1)) and those with predicative adjectives (as in (2)) - the infinitival constituent is the grammatical subject of the copula ${ }^{4}$ and at the same time it is the subject of predication of the predicative adverb or adjective.

Patejuk and Przepiórkowski 2020: fn.8 note in passing that in such constructions "adjectives are sometimes perceived as degraded with respect to the corresponding adverbs" and that " $\mathrm{t}] \mathrm{h}$ he are also much less frequent in the National Corpus of Polish", although they do not provide any quantitative data to support these claims. The following two sections report on a detailed corpus-based investigation of the number and range of adverbs $(\$ 2)$ and adjectives $(\$ 3)$ that occur in the constructions at hand. In particular, the results

2 See also Przepiórkowski 2019 on the special case of sZKODA 'pity', wSTYD 'shame', and żAL 'regret'.

${ }^{3}$ Such constructions are briefly mentioned in Szupryczyńska 2001: 264, (21b), and in Saloni 2003: 164-165, (25)-(28); according to the latter, "such sentences seem not to belong to the standard of contemporary Polish." Moreover, Gębka-Wolak 2011: 60 cites in passing the following Internet example, noting the co-occurrence of an adjective and an infinitival phrase, but offers no analysis:

(i) Śmieszne byłoby jednak uznać ten rezultat za ridiculous.ADJ.NOM.SG.N would be.3SG.N however consider.INF this result as imponujacy.

impressive

'But it would be ridiculous.ADj to consider this result (as) impressive.'

The ISJP dictionary (Bańko 2000) notes occurrences of BYĆ 'be’ with predicative adjectives referring to situations expressed by a sentential clause, but it does not mention constructions with a predicative adjective and an infinitival phrase (cf. Saloni 2000: 11).

${ }^{4}$ In the context of predicative adverbs, this claim appears already in Grzegorczykowa 1975: $35-36$. 
presented in these sections quantitatively support the claim that predicative adverbs occur with infinitival subjects much more frequently - an order of magnitude or two more frequently - than predicative adjectives.

The two sets of data differ not only quantitatively, but - apparently - also qualitatively, i.e., in what kinds of predicates found in the corpus with infinitival predicands are realised as adverbs, and what kinds - as adjectives. We argue (in $\$ \$ 4.1-4.2$ ) that - despite appearances - these qualitative differences are the result of lexical gaps: some predicative meanings may only be expressed by one element of the adjective-adverb pair because the other element either does not exist at all or has a different meaning. In other words, there are no general semantic constraints on whether a predicate is expressed as an adverb or as an adjective, even though there is a general syntactic preference for the adverbial construction. We also show (in $\$ 4.3$ ) that corpus examples support a hypothesis concerning this syntactic preference suggested in Patejuk and Przepiórkowski 2020.

The main empirical basis of these considerations is the National Corpus of Polish (Pol. Narodowy Korpus Języka Polskiego; http://nkjp.pl/; Przepiórkowski et al. 2011, 2012). All NKJP examples were drawn from - and statistics were based on - the 300-million-token (250-million-word) balanced (in the sense defined in Górski and Łaziński 2012) subcorpus of NKJP. The secondary sources of examples are the 9.4-billion-token (7.7-billion-word) Polish Web 2012 corpus (henceforth, PlWeb2012) available via Sketch Engine (http://www.sketchengine.eu; Kilgarriff et al. 2008, 2014), as well as the Internet (via the Google search engine).

\section{Predicative adverbs with infinitival subjects}

The following Poliqarp ${ }^{5}$ query was used to find predicative adverbs with infinitival subjects in the balanced subcorpus of NKJP:

(3) a. [pos=adv \& degree=".*"] [base=być \& pos!=bedzie \& number=sg \& person!="pri|sec"] [pos=inf] within s

b. "a degree adverb, followed by an appropriate form of the copula BYć 'be' (no future tense, number must be singular, person cannot be $1^{\text {st }}$ or $2^{\text {nd }}$ ), followed by an infinitive verb, all within a single sentence"6

\footnotetext{
${ }^{5}$ See http://poliqarp.sourceforge.net/ (Przepiórkowski et al., 2004; Janus and Przepiórkowski, 2007). Poliqarp interface to NKJP is available at http://nkjp.pl/poliqarp/.

${ }^{6}$ The degree=" . * " specification ("the degree attribute must have some value") removes from consideration multiple occurrences of locative and temporal nongradable adverbs such as TU 'here, тAM 'there,' wTEDY 'then', zawsze 'always', etc. The pos ! =bedzie specification ("no future tense BYć 'be"') removes multiple false positives resulting from the fact that - apart from acting as a predicative copula - future forms of BYć 'be' may combine with an infinitive verb to form future tense. The requirement of third person must be stated as pers!="pri | sec" rather than the more direct pers="ter" as past forms are not explicitly marked for person in NKJP. The recall of this query could be increased in various ways, e.g., by allowing for an optional conditional particle $\mathrm{BY}$ around BYć 'be' or an optional negation before the infinitive verb.
} 
This query resulted in 12,060 matches, such as (1) and (4)-(6), few of which (less than $1 \%$ ) were false positives. ${ }^{7}$

(4) Czy trudno było zdobyć materialy?

Q difficult.ADV was.3sG.N obtain.INF materials

'Was it difficult.ADV to obtain the materials?' (NKJP)

(5) Latwiej jest dyskutować o rzeczach ważnych.

easy.ADV.CMP is.3sg discuss.INF about things important

'It is easier.ADV to discuss important things.' (NKJP)

(6) Jak dobrze jest żyć!

how good.ADV is.3sg live.INF

'How good.ADV it is to live!' (NKJP)

The most common adverbs, occurring in this construction at least 10 times, are listed in Table 1.

Table 1. The most common - among the results of query (3) run on the balanced subcorpus of NKJP - adverbs in the predicative construction with infinitival subjects

\begin{tabular}{|r|l|l|}
\hline 4937 & TRUDNO & 'difficult' \\
\hline 2163 & ŁATWO & 'easy' \\
\hline 2083 & DOBRZE & 'good' \\
\hline 446 & CIĘŻKo & 'hard' (lit. 'heavy') \\
\hline 263 & MIŁO & 'nice' \\
\hline 233 & PRZYJEMNIE & 'pleasant' \\
\hline 231 & NIEŁATWO & 'not easy' \\
\hline 172 & WYGODNIE & 'comfortable' \\
\hline 161 & NIETRUDNO & 'not difficult' \\
\hline 132 & PROSTO & 'straightforward' \\
\hline 117 & BEZPIECZNIE & 'safe' \\
\hline 114 & FAJNIE & 'nice' \\
\hline 74 & KORZYSTNIE & 'advantageous' \\
\hline 73 & TANIO & 'cheap' \\
\hline 59 & ŹLE & 'bad' \\
\hline 52 & PRZYKRO & 'unpleasant, sorry' \\
\hline
\end{tabular}

\begin{tabular}{|l|l|l|}
\hline 38 & ROZSĄDNIE & 'reasonable' \\
\hline 37 & NIEBEZPIECZNIE & 'unsafe, dangerous' \\
\hline 32 & PRÓŻNO & 'in vain' \\
\hline 31 & CUDOWNIE & 'wonderful' \\
\hline 28 & PIĘKNIE & 'beautiful' \\
\hline 27 & NIEDOBRZE & 'not good' \\
\hline 25 & WSPANIALE & 'great' \\
\hline 24 & DZIWNIE & 'strange' \\
\hline 22 & CIEKAWIE & 'interesting' \\
\hline 21 & GEUPIO & 'stupid, awkward' \\
\hline 20 & NIEZRĘCZNIE & 'awkward' \\
\hline 18 & PRAKTYCZNIE & 'practical' \\
\hline 12 & ZDROWO & 'healthy' \\
\hline 12 & ZABAWNIE & 'amusing' \\
\hline 11 & SMUTNO & 'sad' \\
\hline 11 & MĄDRZE & 'wise' \\
\hline
\end{tabular}

7 These false positives include 19 occurrences of TAK 'so', 18 occurrences of WCZEŚNIE 'early' and Późno 'late' in expressions such as za wcześnie jest mówić... 'it is too early to speak..., as well as 14 occurrences of wOLNO 'allowed, possible (deontic)', which should be classified as a defective verb inflecting only analytically rather than as an adverb (cf. Wiśniewski 1989: 188-189). 
Clear semantic classes are discernible among the results of query (3). ${ }^{8}$ The most conspicuous is that of adverbs of difficulty or lack thereof: TRUDNO 'difficult', NiETRUdno 'not difficult', CiĘżKo 'hard', ŁaTwo 'easy', NIEŁaTwo 'not easy', PRosto 'straightforward'. Together, they account for $67 \%$ of the matches. At least some occurrences of adverbs such as WYGODNIE 'comfortable', NIEWYGODNIE 'uncomfortable', PRAKTYCZNIE 'practical', LEKKo 'light, easy', and DOGODNIE 'convenient' should also be included in this class.

A related but much smaller class is that of teleological adverbs: PRÓżno and DAREMNIE - both 'in vain', sKUTECZNIE and EFEKTYWNIE 'effective', uŻyTECZNIE 'useful', PORĘCZNIE 'handy', NIEPOŻYTECZNIE 'not useful', CELOWo 'purposeful'.

Another related class contains adverbs which indicate benefit or lack thereof, especially KORZYSTNIE 'advantageous' (most occurrences in the comparative degree), owOCNIE 'fruitful', EKONOMICZNIE 'economical', but also TANIO 'cheap' (all matches in comparative or superlative degree), DROGo 'expensive' (comparative), oszczęDNIE 'frugal', etc. Perhaps szyвко 'fast' and кRótко 'brief' could also be included here - both occurred only in the comparative form, indicating gain in terms of time.

A clearly distinct and relatively coherent class is that of psych adverbs such as MIŁO 'nice', PRZYJEMNIE 'pleasant', RAŹNO 'pleasant' (because of good company), ZABAWNIE 'amusing', RADOŚNIE 'joyful', wESOŁo 'cheerful', śMIESZNIE 'funny', вŁOGo 'blissful', ROZKoszNie 'delightful', sMUtno 'sad', NUDNo 'dull', NIEMIŁO 'not nice', NIEPRZYJEMNIE 'unpleasant', at least some uses of sTRASZNIE 'horrible', PRZYKRo 'unpleasant, sorry', CIEKAWIE 'interesting', etc.' Such adverbs occurred in over $5 \%$ of the matches. We will also include here the very few adverbs referring to bodily sensations such as CIEPŁO 'warm' and some literally used - occurrences of WYGODNIE 'comfortable' and NIEWYGODNIE 'uncomfortable'.

Finally, there is a large and amorphous class of adverbs that indicate various degrees of approval or desirability - or lack thereof. Some such adverbs are very general, e.g.: DOBRZE 'good', NIEDOBRZE 'not good', FAJNIE 'nice', NIEFAJNIE 'not nice', źle 'bad', wSPANIALE and śWIETNIE 'great', optyMalNie 'optimal', ZAJEBiście 'excellent' (vulgar, becoming colloquial), воsкo 'divine' (colloquial), OKROPNIE and FATALNIE 'awful', WŁAściWIE 'appropriate', perhaps some uses of STRASZNIE 'horrible'.

Some refer to wisdom (or, less often, lack thereof), e.g., ROzsĄDNIE 'reasonable', MĄDRZE 'wise', sENSOWNIE 'sensible', ROZUMNIE 'reasonable', ROZTROPNIE

8 The classification below is influenced by the first author's discussions with Agnieszka Morusiewicz; it differs from - but is related to - a classification proposed in Morusiewicz 2020, an MSc thesis written under the supervision of the first author.

${ }^{9}$ See Rozwadowska 2017 for a recent overview on psych verbs and adjectives. 
and PRZEZORNIE 'prudent', RACJONALNIE 'rational', SPRYTNIE 'clever', GENIALNIE 'brilliant', DALEKOWZROCZNIE 'farsighted', NIEMĄDRZE 'not wise', NIEROZSĄDNIE 'not reasonable', IDIOTYCZNIE 'idiotic', ABSURDALNIE 'absurd'.

Aesthetic predicates are often used here, usually metaphorically: PIĘKNIE and PRZEPIĘKNIE 'beautiful', CUDOWNIE and CUDNIE 'wonderful', ŁADNIE 'pretty', NIEŁAdNIE 'ugly', BRZYDKo 'ugly', stYlowo 'stylish', PRZYSTOJNIE 'handsome', ELEGANCKO 'elegant', NIEELEGANCKO 'not elegant', zGRABNIE 'shapely, deft'. Also a predicate referring to taste, sŁODKo 'sweet', is used metaphorically in this construction.

Some of these aesthetic predicates are used with moral meanings or refer to norms of behaviour, especially, ŁADNIE 'pretty', NIEŁADNIE 'ugly', and BRZYDKO 'ugly'. Other adverbs refer to moral values more directly, e.g.: SZLACHETNIE 'noble', UCZCIWIE 'honest', NIEUCZCIWIE 'dishonest', sŁUsZNIE 'fair', NIESŁUSZNIE 'unfair', PRZYZWOICIE 'decent', NIEPRZYZWOICIE 'indecent', RZETELNIE 'honest, thorough', zAsZCZYTNIE 'honourable', sTOsowniE 'proper, appropriate, MORALNIE 'moral', ETYCZNIE 'ethical', GODNIE 'honourable, dignified', GODZIWIE 'fair, honourable', NIEGODZIwIE 'unfair, dishonourable', HONOROwO 'honourable', SPRAWIEDLIWIE 'just', NIESPRAWIEDLIWIE 'unjust', NIELOJALNIE 'disloyal', GRZECZNIE 'polite', NIEGRZECZNIE 'impolite, rude', UPRZEJMIE 'courteous', NIELUDZKO 'inhuman', NIEHUMANITARNIE 'inhumane'.

Relatedly, some adverbs indicate awkwardness or strangeness (or, rarely, lack thereof), e.g.: NIEZRĘCZNIE 'awkward', GEUPIO 'stupid', often used with the meaning 'awkward' or 'inappropriate', DZIWNIE and DZIwNo 'strange', ZRĘCZNIE 'not awkward'. Moreover, some predicative adverbs refer to appropriateness in terms of norms, e.g., MODNIE 'fashionable', NIEMODNIE 'not fashionable', POPRAWNIE 'correct', etc.

Finally, more specialised adverbs indicate goodness or badness in terms of safety, e.g. RYZY KOWNIE 'risky', BEZPIECZNIE 'safe', and NIEBEZPIECZNIE 'unsafe, dangerous', or health, e.g. zDROwo 'healthy' and NIEZDROwo 'unhealthy'.

Obviously, the above classification is rather coarse, and some adverbs - for example, DOBRZE 'well' - could reasonably be placed in a number of classes distinguished here. We hope that it will provide inspiration - or be a subject of critique - which will lead to a more comprehensive classification based on better criteria than semantic intuition.

\section{Predicative adjectives with infinitival subjects}

The following query was used to find predicative adjectives with infinitival subjects in the balanced subcorpus of NKJP: 
(7) a. [pos=adj \& case=nom \& number=sg \& gender=n]

[base=być \& pos!=bedzie \& number=sg \&

person!="pri|sec"] [pos=inf] within s

b. "an adjective (nominative, ${ }^{10}$ singular, neuter), followed by an appropriate form of the copula BYć 'be' (no future tense, number must be singular, person cannot be $1^{\text {st }}$ or $2^{\text {nd }}$ ), followed by an infinitive verb, all within a single sentence"

This query resulted in 271 matches, such as (2) and (8)-(10), about 100 of which (around $37 \%$ ) were false positives. ${ }^{11}$

(8) Najważniejsze jest ufać ludziom.

important.ADJ.SUP.NOM.SG.N is.3sg trust.INF people

'It is most important.ADJ to trust people.' (NKJP)

(9) Oficjalnie wskazane jest okazywać jak największy

officially advisable.ADJ.NOM.SG.N is.3SG demonstrate.INF how greatest wstręt do Zachodu.

disgust towards West

'Officially, it is advisable.ADJ to show the greatest possible disgust towards the West.' (NKJP)

(10) Niemożliwe jest grać $w$ takich warunkach dobry tenis. impossible.ADJ.NOM.SG.N is.3sG play.INF in such conditions good tennis 'It is impossible.ADJ to play good tennis in such conditions.' (NKJP)

The ratio of the true positives of query (3) to the true positives of query (7) is 69.25 to 1, i.e., in the balanced subcorpus of NKJP, predicative adverbs occur almost 70 times more frequently than predicative adjectives in the "predicate + copula + infinitival subject" construction.

The most common adjectives, occurring in this construction at least twice, are listed in Table $2 .{ }^{12}$ What is striking about this list is that many of the most frequent adjectives have modal meanings, as in (8)-(10). This is most clear in the case of MożLIWY 'possible', NIEMOŻLIWY 'impossible', and KONIECZNY 'necessary'. But also the two most frequent adjectives, wAŻNY 'important' and WSKAZANY 'advisable, desirable', clearly express modality, namely bouletic or

${ }^{10}$ Also instrumental forms can occur in this construction, but - somewhat surprisingly a query analogous to (7) with case=nom replaced by case=inst returns only one result, and it is a false positive. (In the case of the full NKJP, two results are returned, both false positives).

${ }^{11}$ For example, 52 occurrences of forms of Gotowy 'ready', as in (i) below, 19 occurrences of ZDOLNY 'capable', 13 of sKŁONNY 'inclined', etc.

(i) Miasto gotowe jest pomóc policji... city.NOM.SG.N ready.ADJ.NOM.SG.N is.3sG help.INF police.DAT

'The city is ready to help the police...' (NKJP)

12 As is common, nominative singular masculine forms are given as adjectival lemmata, even though the forms occurring in the discussed construction are neuter. 
teleological, while ZAKAZANY 'forbidden' expresses deontic modality. Assuming the general division of modalities into root (also called circumstantial) and epistemic (Kratzer 1981, 2012), modal adjectives occurring in this construction express root (deontic, teleological, bouletic, etc.) - not epistemic - modality. Such adjectives account for about $67 \%$ of the correct matches of query (7).

Table 2. The most common - among the results of query (7) run on the balanced subcorpus of NKJP - adjectives in the predicative construction with infinitival subjects

\begin{tabular}{|r|l|l|}
\hline 70 & WAŻNY & 'important' \\
\hline 12 & WSKAZANY & 'advisable, desirable' \\
\hline 11 & NIEMOŻLIWY & 'impossible' \\
\hline 6 & ZABAWNY & 'amusing' \\
\hline 6 & KONIECZNY & 'necessary' \\
\hline 3 & ZAKAZANY & 'forbidden' \\
\hline 3 & SŁUSZNY & 'fair' \\
\hline 3 & RYZYKOWNY & 'risky' \\
\hline 3 & ROZSĄDNY & 'reasonable' \\
\hline 3 & MOŻLIWY & 'possible' \\
\hline 3 & CIEKAWY & 'interesting' \\
\hline 2 & ZWIERZĘCY & 'animal' \\
\hline 2 & ZASADNY & 'justified' \\
\hline 2 & STRASZNY & 'horrible' \\
\hline 2 & NIESAMOWITY & 'amazing' \\
\hline 2 & MODNY & 'fashionable' \\
\hline 2 & FASCYNUJĄCY & 'fascinating' \\
\hline 2 & FAJNY & 'nice' \\
\hline 2 & CELOWY & 'intentional, purposeful' \\
\hline & & \\
\hline
\end{tabular}

Other predicative adjectives among the matches of query (7) represent all the classes distinguished in $₫ 2$. The difficulty class is represented by single - but acceptable - occurrences of TRUDNY 'difficult' (as in (11), in the superlative), ŁATWY 'easy' (as in (12), also superlative), NIEŁATWY 'not easy', PROSTY 'simple'.

(11) Ale i tak najważniejsze i najtrudniejsze było but and so important.ADJ.SUP.NOM.SG.N and difficult.ADJ.SUP.NOM.SG.N was.3sG.N dotknąć tych dobrych tonów wielkiej osobowości Ojca Świętego. touch.Inf these good tones great personality Father Holy 'Still, the most important.ADJ and most difficult.ADJ thing was to touch the good tones of the great personality of the Holy Father.' (NKJP) 
(12) Dla jednego najłatwiejsze jest wpaść $w$ manię religijna; for one easy.ADJ.SUP.NOM.SG.N is.3sG fall.INF in mania religious dla drugiego: dokonywać bohaterstw... for another perform heroisms

'For one, it is easiest.ADJ to fall into a religious mania; for the other: to perform heroisms...' (NKJP)

The class of teleological adjectives is represented by two occurrences of CELOWY 'purposeful' (see (28) in $\$ 4.2$ ) but, as mentioned above, some of the modal adjectives may express teleological modality.

A few adjectives of benefit - or lack thereof - also occurred among the matches, including PRZYDATNY 'useful' (as in (13)), as well as - arguably also belonging to this class - POUCZAJĄCY 'instructive'.

$\begin{array}{lllll}\text { (13) ...czasami przydatne } & \text { jest czytać pierwsze } & \text { posty... } \\ \text { sometimes } & \text { useful.ADJ.NOM.sG.N is.3sg read.INF first } & \text { posts }\end{array}$

'...sometimes it's useful.ADJ to read the first posts...' (NKJP)

More frequent (about 12\% of matches) are psych adjectives, e.g., ZABAWNY 'amusing' (as in (2)), FASCYNUJACCY 'fascinating' (see (14)), FAJNY 'nice', WZRUSZAJĄCY 'moving, touching', CIEKAWY 'interesting', śMIESZNY 'funny', PRZYKRY 'unpleasant, sorry', PRZERAŻAJĄCY 'frightening', PODNIECAJĄCY 'eXciting', etc.

(14) Fascynujące jest śledzić losy tych ludzi... fascinating.ADJ.NOM.SG.N is.3sG track.INF fates these people 'It is fascinating.ADJ to follow the fates of these people...' (NKJP)

The amorphous class of approval adjectives is also well represented, with examples illustrating various subclasses mentioned in the previous section. So, general approval - or lack thereof - is expressed by STRASZNY 'horrible' (as in (15)), NIESAMOWITY 'amazing', and WSPANIAŁY 'great'. Approval in terms of wisdom is represented by ROZSĄDNY 'reasonable' (as in (16)), RACJONALNY 'rational', LOGICZNY 'logical'. Aesthetic adjectives in the sample are represented by OBRZYDLIWY 'hideous', actually used as a moral term. More literally moral adjectives include SŁUSZNY 'right' (see (17)), ZASADNY 'justified', NIESŁUSZNY 'not right', NIEMORALNY 'immoral', ETYCZNY 'ethical', as well as ZwiERZĘCY 'inhuman', lit. 'animal'.

(15) Straszne jest chcieć, chcieć mieć, chcieć posiadać. terrible.ADJ.NOM.SG.N is.3SG want.INF want.INF have.INF want.INF possess.INF 'It's terrible.ADJ to want - to want to have, to want to possess.' (NKJP)

(16) ...rozsądne jest zakończyć picie... reasonable.ADJ.NOM.SG.N is.3sg end.INF drinking

'...it is reasonable.ADJ to stop drinking...' (NKJP) 
(17) Stąd uznajemy, że słuszne jest zadbać $o$ to... hence recognise.1PL COMP right.ADJ.NOM.SG.N is.3sG take_care.INF about this 'Hence, we recognise that it is right.ADJ to take care of this...' (NKJP)

Again, a couple of predicates express awkwardness, e.g. KRĘPUjĄCY 'embarrassing' and KŁOPOTLIWY 'bothersome, awkward', a couple refer to norms, e.g. MODNY 'fashionable' and NORMALNY 'normal', and a couple to safety, e.g. NIEBEZPIECZNY 'unsafe, dangerous' and RYZYKOWNY 'risky'.

\section{Discussion}

Let us summarise the findings of the previous two sections. First of all, they empirically justify the claim that, with infinitival subjects, predicative adverbs are used much more frequently - almost two orders of magnitude more frequently - than predicative adjectives. Second, such predicative adverbs belong to a handful of semantic classes: they express difficulty or easiness, emotional attitude, beneficence, and approval - either general, or in terms of wisdom, appearance, moral values, awkwardness, or other norms. Third, while much rarer, predicative adjectives also represent all these classes, but they may additionally - and most conspicuously - refer to root modalities, e.g.: MOŻLIWY 'possible', NIEMOŻLIWY 'impossible', KONIECZNY 'necessary', ZAKAZANY 'forbidden', wSKAZANY 'advisable, desirable', and the most frequent predicative adjective among the matches, WAŻNY 'important'.

Two questions immediately arise. First, why are there no modality adverbs among the predicative adverbs? Second, why do so few occurrences of predicative adjectives belong to the other - non-modality - classes; is it the case that for most predicative adverbs the corresponding adjectives cannot be used predicatively with infinitival subjects at all? We address these questions in the following subsections, starting with the second question.

\section{Ranges of predicative adverbs and adjectives}

In the case of four of the 32 most frequent predicative adverbs listed in Table 1, also the corresponding adjectives are among the most frequent predicative adjectives listed in Table 2. These are: ZaBaWNIE and ZABAWNY 'amusing', ROZSĄDNIE and ROZSĄDNY 'reasonable', CIEKAWIE and CIEKAWY 'interesting', and FAJNIE and FAJNY 'nice'. However, out of the other 28 adverbs in Table 1, for 21 no corresponding predicative adjective was found in the results of query (7). For example, while the adverb DobRzE 'good' was observed 2083 times, the adjective DOBRY 'good' was not among the observed predicative adjectives. Other such "missing" adjectives are: CIĘżKI 'hard', lit. 'heavy', MIŁY 'nice', PRZYJEMNY 'pleasant', WYGODNY 'comfortable', NIETRUDNY 'not difficult', BEZPIECZNY 'safe,' 
KORZYSTNY 'advantageous', TANI 'cheap', ZŁY 'bad', PRÓŻNY 'in vain', CUDOWNY 'wonderful', PIĘKNY 'beautiful', NIEDOBRY 'not good', DZIWNY 'strange', GŁUPI 'stupid', NIEZRĘCZNY 'awkward', PRAKTYCZNY 'practical', ZDROWY 'healthy', SMUTNY 'sad', and MĄDRY 'wise'. Are these adjectives banned from occurring in predicative constructions with infinitival subjects, or is their absence among the matches of query (7) purely accidental?

It turns out that, in the case of the vast majority of these adjectives, fully acceptable examples of their predicative uses with infinitival subjects can readily be found in the PlWeb2012 corpus or in the Internet. For example, in the case of the adjective DOBRY 'good', a Sketch Engine query to PlWeb2012 analogous to (7) found 115 results, many of them of spotless acceptability, e.g.: ${ }^{13}$

(18) A dla mnie dobre jest chodzić droga Pańską.

and for me good.ADJ.NOM.SG.N is.3sg walk.INF way Lord

'And it is good.ADJ for me to walk in the way of the Lord.' (PlWeb2012)

(19)...dla mnie na obecnym etapie najlepsze jest być sobq...

for me on current stage good.ADJ.SUP.NOM.SG.N is.3sg be.INF self

'...for me, at this stage, the best.ADJ thing is to be myself...' (PlWeb2012)

This suggests that while predicative adjectives are generally dispreferred in constructions with infinitival subjects, they are not systematically banned; usually either may be used.

Patejuk and Przepiórkowski 2020: $\$ 3$ mention that, when either an adverb or an adjective may be used with an infinitival predicand, "there is no systematic difference in meaning between the two constructions". Corpus data support this observation. For example, there is no discernible difference in meaning between ZABAWNIE and ZABAWNY 'amusing' as they are used in (1)-(2). Either sentence may be transformed to its dual, expressing the same proposition:

(20) Dlaczego zabawniejsze jest zostać uwiedzionym przez why amusing.ADJ.CMP.NOM.SG.N is.3sg become.INF seduced by poetke niż przez ekonomistkę?

poet.F than by economist.F

'Why is it more amusing.ADJ to be seduced by a poet than by an economist?'

(21) Wanda żartowała, że całkiem zabawnie jest wracać $z$ Wanda joked COMP quite amusing.ADV is.3sG return.INF from knajpy $z$ własnym mężem.

pub with own husband

'Wanda joked that it is quite amusing.ADV to come back from the pub with one's own husband.'

${ }^{13}$ In fact, a couple of examples with DOBRY 'good', as well as a handful of other adjectives not reported above (including MORALNY 'moral' and sTOSOWNY 'appropriate'), may also be found in the balanced subcorpus of NKJP. They are not among the results of query (7) because of errors in the automatic morphosyntactic annotation of the corpus. Thanks are due to Agnieszka Morusiewicz for noticing this fact. 
Similar attempts to transform other attested examples may result in some awkwardness, especially when an adverb is replaced by an adjective, but not in any clear change of meaning.

However, there are a few exceptions to the generalisation that predicative adverbs and adjectives are interchangeable with infinitival predicands. For example, in the case of the fourth most frequent adverb, cIĘżKo 'hard', lit. 'heavy', the few examples found in larger corpora and in the Internet are of dubious acceptability, e.g., the attested (22) seems to be much less acceptable than the version with the corresponding adverb in (23): ${ }^{14}$

(22) 'Ciężkie jest być Cyganką.

hard.ADJ.NOM.SG.N is.3sg be.INF Gypsy

'It is hard.ADJ to be a Gypsy'. (Google)

(23) Ciężko jest być Cyganką.

hard.ADV is.3sg be.INF Gypsy

'It is hard.ADV to be a Gypsy.'

Another such adjective with no fully acceptable occurrences in the construction at hand - not even in very large corpora - is PRóżNY 'in vain'.

We hypothesise that these omissions are due to one of Grice's (1975: 46) maxims of manner, namely, "avoid ambiguity". As adjectives, both CIĘżKI and PRÓŻNY have a number of meanings which the corresponding adverbs cIĘż́Ko and PRóżNo lack. In particular, the adverb PRóżNo may only mean 'in vain', while the adjective PRóżny may also mean 'vain' as in 'vanity' ${ }^{15}$ and 'empty'. Hence, the "avoid ambiguity" maxim implies strong preference to use the unambiguous adverb rather than the ambiguous adjective to express in vain'. Similarly, the main meaning of the adjective CıĘżKI is the literal 'heavy', and according to the corpus-based ISJP dictionary - it has many more meanings than the adverb cį̨żko. This adverb not only has fewer meanings, but it also very rarely refers to literal heaviness. Hence, in order to make reference to non-literal difficulty (rather than literal heaviness) clear, one should use the adverb rather than the adjective.

As we will see below, similar differences between the meanings of adjectives and related adverbs are responsible for the fact that only adjectives may be used predicatively with infinitival subjects to express various modalities.

${ }_{14}$ An anonymous reviewer notes that (22) becomes more acceptable when the nominative ciężkie is replaced by the instrumental ciężkim. We do not have clear acceptability preferences here, but we note that the adverbial version in (23) is clearly more acceptable than either adjectival version.

15 This, in fact, seems to be the most frequent meaning, given the ordering of meanings in the corpus-based ISJP dictionary (Bańko 2000). 


\section{Scarcity of modal adverbs}

Here we return to the question why - in predicative constructions with infinitival subjects - only adjectives are used to express prototypical modal meanings of possibility and necessity, and not adverbs.

The first thing to note is that the vast majority of modal adverbs and adjectives only express epistemic - not root - modality. This is explicitly noted in Rozumko 2019: 49, 79, a recent monograph on modal adverbs in Polish and English, where among the seven postulated classes of Polish modal adverbs, six are purely epistemic and one - that of adverbs of necessity - contains just a few adverbs that can express root (mainly deontic) modalities, e.g. KONIECZNIE 'necessary'.

The second observation is that epistemic predicates in general cannot predicate of infinitival subjects. As noted in Danielewiczowa 2008: 51, many epistemic (adverbs and) adjectives, such as (PRZYPUSZCZALNIE and) PRZYPUSZCZALNY 'presumable' or (EWENTUALNIE and) EWENTUALNY 'possible, ${ }^{16}$ cannot occur in predicative positions at all. But - we may add - even those that can, such as PRAWDOPODOBNIE and PRAWDOPODOBNy 'probable' (see (24)-(25)), cannot combine with infinitival predicands (see (26) for an attempt):

(24) Wygrana była prawdopodobna.

victory.NOM.sG.F was.3sG.F probable.NOM.SG.F

'The victory was likely.'

(25) Prawdopodobne było, że wygrają. probable.NOM.SG.N was.3SG.N COMP win.3PL

'It was likely that they would win.'

(26) * Prawdopodobne było wygrać. probable.NOM.sG.N was.3sG.N win.INF Intended: 'Winning was likely'.

Finally, and this is the reason why some modal meanings may be expressed by predicative adjectives combining with infinitival predicands but not by predicative adverbs, adverbs corresponding to most of the few non-epistemic

${ }^{16}$ In fact, eWENTUALNY may be used predicatively in its specialised legal meaning, on which zamiar ewentualny (Lat. dolus eventualis) 'recklessness', lit. 'intention possible', refers to an agent's knowledge that his or her action may result in a punishable outcome, without the actual intention of reaching this outcome, e.g.:

(i) Sędzia uznał jednak, że jego zamiar był ewentualny, a nie bezpośedni. judge concluded however сомp his intention was possible and not direct 'However, the judge concluded that his action was reckless rather than intentional.' (Google)

Arguably, the modality expressed by this specialised legal meaning of EWENTUALNY is not epistemic but rather future or metaphysical (see, e.g., Condoravdi 2001 and Werner 2006 on metaphysical and future modalities). 
modal adjectives either do not exist at all or do not have the same modal meanings. So usually (but see below) the only way to express (non-epistemic) modal predication is to use an adjective.

Let us consider the most frequent adjective in Table 2, i.e., WAŻNY 'important'. As noted in Patejuk and Przepiórkowski 2020: fn.10, while the adverb WAŻNIE exists, it has a very specialised meaning: "it means 'binding, valid', as in małżeństwo ważnie zawarte 'valid marriage', lit. 'marriage bindingly established'. The English sentential adverb importantly may be expressed in Polish as co ważne lit. 'what('s) important"'. Hence, in order to express the general 'important' modality, the adjective WAŻNY must be used instead.

Some of the other modal adjectives have no corresponding adverbs at all. This holds for the second most frequent such adjective, WSKAZANY 'advisable, desirable, as well as for other adjectivised participles such as NIEWSKAZANY 'not advisable', ZAKAZANY 'forbidden', and POŻĄDANY 'desired'.

In the case of Możliwy 'possible' and NIEMOŻLiwy 'impossible', derivationally related adverbs do exist, but - as in the case of WAŻNY 'important' vs. WAŻNIE 'legally binding' - they have very specific meanings, different from the general modal meanings of the corresponding adjectives. For example, the ISJP dictionary lists two meanings of the adverb MOŻLIwIE: it may either combine with adjectives and adverbs to express a high value - as high as possible on a scale (e.g., możliwie szybko, lit. 'possibly quickly', means 'as quickly as only possible'), or it may be used colloquially with the meaning 'satisfactory' (as in wyglada możliwie 'looks more or less acceptable'). By contrast, in the case of the adjective MOŻLIWY, the first meaning given in ISJP is the root modal meaning 'possible', and the third meaning refers to epistemic possibility. Similarly for NIEMOŻLIWIE: this adverb exists but it may only mean something like 'awful' or 'very', rather than 'impossible'.

So the lack of modal adverbs acting as predicates of infinitival subjects is not a matter of some deep grammatical principle, but can rather be explained in terms of lexical gaps (lack of adverbial equivalents of some adjectives) and differences in meanings of some adjectives and their corresponding adverbs. This conclusion is confirmed by the fact that, exceptionally, some modal meanings may be expressed equally well by an adjective and an adverb. The case in point is the adjective CELOWY and the adverb CELOWO, both meaning 'purposeful', i.e., expressing teleological modality. The matches of queries (3) and (7) include one occurrence of the adverb (see (27)) and two occurrences of the adjective (including (28)); few but all fully acceptable:
(27) ...pracę nad zdolnościami szybkościowo-siłowymi... celowo jest work.ACC on abilities speed-strength purposeful.ADV is.3sg łączyć $\quad z \quad$ kształtowaniem różnorodnych KZM. combine.INF with shaping various CMSs
'...it is purposeful.ADV to combine work on speed and strength abilities with shap- ing various coordinating motor skills.' (NKJP)


(28) Czy celowe jest walczyć o nie...? Q purposeful.ADJ.NOM.SG.N is.3sG fight.INF for them 'Is it purposeful.ADj to fight for them...?' (NKJP)

Another example of a modal adverb predicating of infinitival subjects is the rare colloquial and dialectal musowo 'necessary':

(29) Musowo było postarać się o buteleczkę ze smoczkiem... necessary.ADV was.3sG.N procure.INF RM about bottle with teat 'It was necessary.ADV to get a bottle with a teat.' (NKJP)

Hence, there is no general ban on modal adverbs in the construction at hand. Rather, epistemic predicates (whether adverbial or adjectival) are in general incompatible with infinitival predicands, and in the case of most non-epistemic modal predicates, there are lexical gaps and differences in meaning between adjectives and adverbs. These factors combine to create the impression that modal predicates may only be expressed as adjectives.

Let us finish this section with an open problem. Considerations above do not suffice to explain why the modal adjective KONIECZNY 'necessary' is perfectly acceptable as a predicate combining with infinitival subjects (it occurred 6 times; see Table 2), while no acceptable occurrences of the adverb KonIECZNIE, which exists and has a modal meaning, were found even in much larger corpora. One of the found examples of the adjective KONIECZNY, with two uses of this adjective, is (30); an attempt to use the adverb KonIECZNIE leads to unacceptability, as in (31).

(30) ...nie jest konieczne $\dot{z} y c ́$, konieczne jest $\dot{z}$ eglować... NEG is.3sG necessary.ADJ live.INF necessary.ADJ is.3sG sail.INF

'... it is not necessary.ADJ to live, it is necessary.ADJ to sail...' (NKJP)

$(31){ }^{*}$...nie jest koniecznie $\dot{z} y c ́, \quad$ koniecznie jest $\dot{z} e g l o w a c ́ . .$. NEG is.3SG necessary.ADV live.INF necessary.ADV is.3sG sail.INF

We may only speculate that this is the result of more subtle differences in meaning between the adjective and the adverb: the former is typically used to express teleological modality, and the latter is normally used with bouletic or deontic modality, ${ }^{17}$ not really translatable as 'necessarily', e.g.:

(32) Koniecznie obejrzyj zdjęcia!

necessary.ADV watch.IMP.2sG photos

'You must (= I want you to) see the photos!' (NKJP)

not: 'Necessarily, see the photos!'

17 See, e.g., Danielewiczowa 2012: 151-153, where the adverb kONIECZNIE is characterised as "belonging to the subsystem of volitive-deontic expressions." 
However, since adjectives with bouletic meanings may predicate of infinitival subjects (e.g., POŻĄDANY 'desirable'), it is not clear why the bouletic adverb KONIECZNIE should be prohibited from doing so. We leave this problem for future research.

\section{Analytical possibilities}

We have established that, barring lexical gaps and lexical semantic idiosyncrasies, a predicate combining with an infinitival predicand may be expressed either by an adverb or by the corresponding adjective, without any clear change of meaning. However, constructions with infinitival subjects and predicative adjectives are much rarer than those with predicative adverbs. What is the source of this dispreference?

Patejuk and Przepiórkowski 2020: $\$ 3$ hypothesise that this is because of the relative syntactic complexity of the two constructions. On the basis of, inter alia, extraction facts, they argue that when a predicative adjective combines with an infinitival phrase, the latter must undergo covert nominalisation (resulting in an extraction island). On the other hand, predicative adverbs combine with infinitival phrases directly, so - other things being equal - they are preferred.

They note that this analysis also explains the following set of coordination facts:

(33) Najłatwiej i najtaniej było upłynnić ziarno czy ziemniaki. easy.ADv.sup and cheap.ADv.SuP was.3sG.N sell.INF grain or potatoes 'It was easiest.ADV and cheapest.ADV to sell grain or potatoes.' (NKJP)

(34) Najłatwiejsze i najtańsze było upłynnić ziarno czy ziemniaki. easy.ADJ.suP and cheap.ADJ.SUP was.3sG.N sell.INF grain or potatoes

$(35){ }^{*}$ Najłatwiej i najtańsze było upłynnić ziarno czy ziemniaki. easy.ADV.sup and cheap.ADJ.sup was.3sG.N sell.INF grain or potatoes

(33) is an attested example. It is fully acceptable, as the predicative adverbs combine with the infinitival phrase directly, without need for nominalisation. The analogous (34) is slightly degraded, because here the infinitival phrase must undergo covert nominalisation in order to combine with predicative adjectives. Finally, (35) is clearly unacceptable (also with the reversed order of conjuncts), which is explained by conflicting expectations as to the actual categorial status of the surface infinitival phrase: the adverb expects it to stay infinitival, while the adjective expects it to undergo covert nominalisation.

These facts remain unaccounted for under an alternative analysis, on which the infinitival subject does not undergo nominalisation, and adverbs and adjectives differ in their readiness to predicate of such infinitival subjects. On 
such an analysis, the acceptability of (35), with an adverb and an adjective, could be expected to be somewhere between that of (33) (which contains two adverbs) and (34) (which contains two adjectives). ${ }^{18}$

Naturally occurring examples support the analysis of Patejuk and Przepiórkowski (2020). Consider again (11), repeated below as (36).

(36) Ale i tak najważniejsze i najtrudniejsze było

but and so important.ADJ.SUP.NOM.SG.N and difficult.ADJ.SUP.NOM.SG.N was.3sG.N dotknąc tych dobrych tonów wielkiej osobowości Ojca Świętego. touch.INF these good tones great personality Father Holy 'Still, the most important.ADJ and most difficult.ADj thing was to touch the good tones of the great personality of the Holy Father.' (NKJP)

This example contains the only occurrence of a form of the adjective TRUDNY 'difficult' among the results of query (7). This should be contrasted with the fact that the adverb TRUDNO 'difficult' is the most frequent adverb among the results of query (3). Why was the predicate 'difficult' realised here as an adjective rather than as an adverb? The answer is simple: this was the only possibility, given the need to coordinate it with the predicate 'important', which - as discussed in $\$ 4.2$ - may only be expressed by the adjective WAŻNY 'difficult', not by the adverb WAŻNIE. The presence of the adjective WAŻNY implies that the infinitival phrase is covertly nominalised, and as a nominal it cannot be predicated of by an adverb - hence the use of the adjective TRUDNY 'difficult' rather than the adverb TRUDNO in (36), despite the very strong general preference for the adverb.

The same point can be made on the basis of the following attested example, illustrating coercion in the opposite direction:

(37) Takie rzeczy ciężko, a wręcz niemożliwie jest wycenić... such.ACC things.ACC hard.ADV and even impossible.ADV is price.INF

'Such things are hard.ADV or even impossible.ADV to put a price on.' (PlWeb2012)

Again, as discussed in $\$ 4.2$, the modal meaning expressed by the adjective NIEMOŻLIWY 'impossible' is not normally expressible with the adverb NIEMOżLIWIE. However, given the extraction of takie rzeczy 'such things' from the infinitival phrase, and the use of the adverb ciężko 'hard', lit. 'heavy' (which, as noted in $\$ 4.1$, cannot be replaced with an adjective), the infinitival subject must be analysed as truly infinitival, rather than covertly nominalised. This means that the 'impossible' modality cannot be expressed by an adjective, so the adverb NIEMOżLIWIE has to be coerced to a meaning it does not usually express.

${ }^{18}$ Note that the unacceptability of (35) cannot be alternatively explained with reference to the mythical requirement that only the same categories may be coordinated. As is by now well known, this requirement does not hold in general, and - in particular - it does not apply to predicative positions; see Patejuk and Przepiórkowski 2020 for examples and further references. 


\section{Conclusion}

In this paper we took a closer look at a construction that until recently remained neglected, namely, at predicative adjectives combining with infinitival predicands. In particular, this construction has not been given its due in existing descriptions of the copula, nor - with the exception of the preliminary work in Patejuk and Przepiórkowski 2018, 2020 - is it discussed in the literature on predication or infinitival subjects. We offered a corpus-based comparison of this construction with its better known - and textually much more frequent - sister, where the predicate is realised as an adverb. Contrary to first impressions, there are no systematic differences in the semantic range of predicates realised in one or the other construction; any differences are the results of lexical gaps and sometimes subtle differences in the meanings expressed by an adjective and the corresponding adverb. We also argued that the attested data supports the analysis in Patejuk and Przepiórkowski 2020 on which apparent infinitival phrases undergo covert nominalisation when they combine with adjectival predicates, but not when they combine with adverbial predicates.

\section{Acknowledgements}

We are grateful to Marcin Woliński for providing us with a list of adjectiveadverb derivational correspondences extracted from SGJP (http://sg.jp.pl/; Saloni et al. 2007; Woliński et al. 2020), to Agnieszka Morusiewicz for comments on a previous version of this paper and for discussions that influenced the proposed semantic classification of predicative adverbs, and to two anonymous reviewers for comments that led to various improvements in the text.

Agnieszka Patejuk gratefully acknowledges the Mobilność Plus mobility grant awarded by the Polish Ministry of Science and Higher Education.

\section{References}

Bańko Mirosław, ed. (2000). Inny słownik języka polskiego. Warsaw: Wydawnictwo Naukowe PWN.

Bondaruk Anna (2013). Copular Clauses in English and Polish. Lublin: Wydawnictwo KUL.

Condoravd Cleo (2001). Temporal interpretation of modals: Modals for the present and for the past. In David Beaver, Stefan Kaufmann, Brady Clark, Luis Casillas (eds.), The Construction of Meaning, 59-88. Stanford, CA: CSLI Publications.

Danielewiczowa Magdalena (2008). Opis przysłówków epistemicznych jako wyzwanie teoretyczne. Prace Filologiczne 54, 47-61. 
Danielewiczowa Magdalena (2012). Koniecznie - niekoniecznie. Przypadek językowej asymetrii. In Dorota ZdunkiewiCz-Jedynak (ed.), Słowa i ich opis. Na drogach współczesnej leksykologii, 151-160. Uniwersytet Warszawski, Wydział Polonistyki.

GĘBKA-WolaK Małgorzata (2011). Pozycje składniowe frazy bezokolicznikowej we współczesnym zdaniu polskim. Toruń: Wydawnictwo Uniwersytetu Mikołaja Kopernika.

GóRSKI Rafał L., ŁAZIŃski Marek (2012). Reprezentatywność i zrównoważenie korpusu. In Adam Przepiórkowski, Mirosław Bańko, Rafał L. Górski, Barbara Lewandowska-Tomaszczyк (eds.), Narodowy Korpus Języka Polskiego, 25-36. Warsaw: Wydawnictwo Naukowe PWN.

Grice H. Paul (1975). Logic and conversation. In Peter Cole, Jerry L. Morgan (eds.), Syntax and Semantics, vol. 3: Speech Acts, 41-58. New York: Academic Press.

Grzegorczy Kowa Renata (1975). Funkcje semantyczne i składniowe polskich przysłówków. Wrocław: Zakład Narodowy im. Ossolińskich.

Janus Daniel, Przepiórkowski Adam (2007). Poliqarp: An open source corpus indexer and search engine with syntactic extensions. In Proceedings of the ACL 2007 demo and poster sessions, 85-88. Prague.

Kallas Krystyna (1993). Kilka uwag na temat charakterystyki akomodacyjnej i konotacyjnej leksemów Być. Acta Universitatis Nicolai Copernici: Filologia Polska 40, 27-39.

Kilgarriff Adam, Baisa Vít, Bušta Jan, Jakubíček Miloš, Kovář Vojtěch, Michelfeit Jan, Rychlý Pavel, Suchomel Vít (2014). The Sketch Engine: Ten years on. Lexicography 1, 7-36.

Kilgarriff Adam, Rychly Pavel, Smrž Pavel, Tugwell David (2008). The Sketch Engine. In Thierry Fontenelle (ed.), Practical Lexicography. A Reader, 297-306. Oxford: Oxford University Press.

Kratzer Angelika (1981). The notional category of modality. In Hans J. Eikmeyer, Hannes Rieser (eds.), Words, Worlds, and Contexts: New Approaches in Word Semantics, 38-74. Berlin: De Gruyter.

Kratzer Angelika (2012). Modals and Conditionals: New and Revised Perspectives, chapter 2, 27-69. Oxford: Oxford University Press.

Morusiewicz Agnieszka (2020). Przysłówki predykatywne w języku polskim. Konstrukcje z podmiotem bezokolicznikowym. Master's thesis, University of Warsaw, in progress.

Patejuk Agnieszka, Przepiórkowski Adam (2018). Predicative constructions with infinitival and clausal subjects. In Miriam Butt, Tracy Holloway KING (eds.), The Proceedings of the LFG'18 Conference, 304-324. Stanford, CA: CSLI Publications.

Patejuk Agnieszka, Przepiórkowski Adam (2020). Predicative adverbs: Evidence from Polish. Linguistic Inquiry. DOI: https://doi.org/10.1162/ling_a_00394. Forthcoming.

PrzePIóRKowski Adam (2019). Status gramatyczny predykatywnych sZKoDA, WSTYD, Żal raz jeszcze. Polonica 39, 85-110. DOI: http://dx.doi.org/10.17651/POLON.39.5.

Przepiórkowski Adam, BAŃko Mirosław, Górski Rafał L., LewandowskA-Tomaszczyк Barbara (eds.) (2012). Narodowy Korpus Języka Polskiego. Warsaw: Wydawnictwo Naukowe PWN.

Przepiórkowski Adam, BAŃko Mirosław, Górski Rafał L., LewANdowskA-Tomaszczyk Barbara, ŁAzIński Marek, Pęzik Piotr (2011). National Corpus of 
Polish. In Zygmunt Vetulani (ed.), Proceedings of the $5^{\text {th }}$ Language \& Technology Conference: Human Language Technologies as a Challenge for Computer Science and Linguistics, Poznań, Poland.

Przepiórkowski Adam, Krynicki Zygmunt, DęBowski Łukasz, Woliński Marcin, JANus Daniel, BAŃsKi Piotr (2004). A search tool for corpora with positional tagsets and ambiguities. In Proceedings of the Fourth International Conference on Language Resources and Evaluation, LREC 2004, 1235-1238, Lisbon: European Language Resources Association (ELRA).

Rozumko Agata (2019). Modal Adverbs in English and Polish: A Functional Perspective. Białystok: Wydawnictwo Uniwersytetu w Białymstoku.

Rozwadowska Bożena (2017). Psychological verbs and psychological adjectives. In Martin Everaert, Henk C. Van Riemsdijk (eds.), The Wiley Blackwell Companion to Syntax, 3383-3408. Hoboken, NJ: John Wiley \& Sons, Inc. $2^{\text {nd }}$ edition.

SALONi Zygmunt (1990). Quelques remarques sur les énoncés comportant le verbe być en polonais. Revue des études slaves 62, 361-365.

SALONi Zygmunt (2000). Projekt artykułu hasłowego BYć. Poradnik Językowy 3, 4-15.

SALONi Zygmunt (2003). Jeszcze o zdaniach typu Jest jasne, że... (uzupełnienia artykułu hasłowego być). In Małgorzata GĘBKA-WolaK, Iwona KAPron-CharzyńsKa, Małgorzata Urban (eds.), Studia z gramatyki i leksykologii języka polskiego. Prace dedykowane profesor Marii Szupryczyńskiej, 157-167. Toruń: Wydawnictwo Naukowe Uniwersytetu Mikołaja Kopernika.

SAloni Zygmunt, Gruszczyński Włodzimierz, Woliński Marcin, WoŁosz Robert (2007). Słownik gramatyczny języka polskiego. Warsaw: Wiedza Powszechna.

SALONi Zygmunt, ŚwIDZIŃski Marek (1985). Składnia współczesnego języka polskiego. Warsaw: Wydawnictwo Naukowe PWN. $2^{\text {nd }}$ (changed) edition.

SALONi Zygmunt, ŚwIDZIŃski Marek (2007). Składnia współczesnego języka polskiego. Warsaw: Wydawnictwo Naukowe PWN. $5^{\text {th }}$ edition.

SzUPRYCZYŃska Maria (1995a). Jeszcze o tzw. „predykatywach przysłówkowych”. Polonica 17, 173-187.

SzUPRYCZYŃska Maria (1995b). Klasyfikacja zdań bezpodmiotowych typu Było duszno. Acta Universitatis Nicolai Copernici: Filologia Polska 46, 89-113.

SzUPRYCZYŃska Maria (2001). O zdaniach typu Jest jasne, że... In Włodzimierz Gruszczyński, Urszula Andrejewicz, Mirosław Bańko, Dorota Kopcińska (eds.), Nie bez znaczenia... Prace ofiarowane Profesorowi Zygmuntowi Saloniemu z okazji jubileuszu 15000 dni pracy naukowej, Białystok: Wydawnictwo Uniwersytetu Białostockiego.

Werner Tom (2006). Future and non-future modal sentences. Natural Language Semantics 14, 235-255.

WiśNIEwski Marek (1989). Status gramatyczny tzw. przysłówków odprzymiotnikowych typu duszno, wolno, nieprzyjemnie. Polonica 14, 183-191.

Woliński Marcin, SAloni Zygmunt, WoŁosz Robert, Gruszczyński Włodzimierz, SKowrońska Danuta, Bronk Zbigniew (2020). Słownik gramatyczny języka polskiego. Warsaw. $4^{\text {th }}$ edition. http://sgjp.pl/ (beta).

ŻMigrodzKi Piotr (1991). Semantyczno-składniowy opis czasownika być we współczesnej polszczyźnie. Polonica 15, 23-37. 
Adam Przepiórkowski

Instytut Podstaw Informatyki PAN

ul. Jana Kazimierza 5

01-248 Warszawa

Poland

przepiorkowski.adam@gmail.com

Agnieszka Patejuk

Instytut Podstaw Informatyki PAN

ul. Jana Kazimierza 5

01-248 Warszawa

Poland

agnieszka.patejuk@gmail.com 